\title{
Enthusiasm, Curiosity and Creative Approaches: In Recognition of Philippe Lejeune's Research
}

\section{Christa Hämmerle}

It was in 1988 when I first met Philippe Lejeune. Or, more precisely, when I-probably a bit immodest_-did not give up until I got hold of the French "pope" of the theory on autobiographies at his university office during my stay in Paris. I had been awarded a grant to do research for my PhD thesis here for two months. Several times I went to l'Université Paris X in the north-west of the city, where Philippe Lejeune was a professor. I had heard that he had taken an interest in autobiographical texts written by ordinary people, which corresponded with similar activities of the social historian Michael Mitterauer in Austria. When I finally spoke with Philippe Lejeune, I was immediately fascinated by his kindness, his interest, his appreciation of a young researcher without any obvious qualification. We kept in touch, and later he invited me to present the "Dokumentation lebensgeschichtlicher Aufzeichnungen" in an issue of Cahiers de Sémiotique Textuelle. ${ }^{1}$ I also remember very well: Philippe Lejeune remained patient and completely calm, when the revised proofs of my article-back then sent the old fashioned way by mail-did not arrive in time. He simply gave me a call and we went through the text over the phone-what a great help!

This, of course, is a rather personal memory. But it illustrates Philippe Lejeune's genuine and enthusiastic, always supporting interest in what had developed in various European countries as new autobiographical research. He was at the cutting edge of these developments, and shared with feminist scholars their search for autobiographical source material to detect womens' traces in history and to redefine old terms and contents based on this. In Austria, the same was true for Michael Mitterauer, who had turned to the new history of everyday life ("Alltagsgeschichte"), and collected and published autobiographical texts of lower class people (including many women) at the Department of Economic and Social 
History of the University of Vienna. ${ }^{2}$ Here, he established the already mentioned "Dokumentation lebensgeschichtlicher Aufzeichnungen" in 1983 that still exists, ${ }^{3}$ and where I had the chance to work for almost ten years. Together with Bernd Jürgen Warneken's definition of "popular autobiography (populare Autobiographik)", i.e. research on all sorts of autobiographical texts written by people from underprivileged educational backgrounds, and together with new approaches of women's history, which from the onset have built upon biographical approaches, ${ }^{4}$ Philippe Lejeune's publications helped me define and understand better the forms of writings and the authors' motivations of the texts we collected and analysed at the Vienna institute. This is all the more true because he had the openness, curiosity and-I deliberately use this expression here-the courage to develop and expand his original interest in literate autobiographies. From theories he had presented earlier in the ground-breaking and famous volume Le pacte autobiographique (1976), which focused on a canon of texts by male authors or intellectuals, he moved to research on writings of ordinary people including women and young girls.

It were Philippe Lejeune's way of looking beyond, his openness and his constant reflections about the "écritures ordinaires" that fascinated me. His work also convinced me that there had to be similar source material of earlier times, however hidden it may be. And that it is worthwhile taking these texts seriously and using them as primary sources for substantial historical work. From Philippe Lejeune I learned much about writing motivations and genre discussions, and that we can conceptualise modes or norms of autobiographical writing without snobby prejudices, without subordinating the variety and vast amount of "écritures ordinaires" to cultural imperialism or hegemonic concepts of a "good," a well-written, a meaningful autobiography or diary. On the contrary, through intense and direct correspondence with those who had sent him their diaries he tried to understand why, how and in which situations of life people maintained a dialogue with their "Cher cahier ..."-as one of his books is entitled. In this book Philippe Lejeune, after an appeal published in $L e$ Magazine littéraire in April 1988, presented what 47 diarists had written to him in letter-form about the history, the motivations, practices, style, contents, interruptions etc. of their diary writing. It proved that not only many adolescents or young people kept a diary, but that this writing practice was also more disseminated throughout the population in the second half of the $20^{\text {th }}$ century than commonly assumed. ${ }^{5}$

And what other creative approaches he found for his further works! In light of questions being posed during 1999/2000, he examined if and how the diary-format is practiced via computer and on the internet, which resulted in his book "Cher Écran ...". ${ }^{6}$ Before, Philippe Lejeune also 
deepened the historical perspective of his work, and came to deal more closely with the diaries of young women-a type of personal writing which both contemporaries and literary educated elites (including literary scholars) had long since defined as being of no value, nonsense, boring, and even dangerous to the desired female self. Le Moi des Demoiselles ${ }^{7}$ took these texts seriously! It is an excellent book which was introduced by Lejeune's own "journal d'enquête" of 1991/1992, when he became seized with the idea that many more nineteenth century diaries by young girls must exist than those few which were already well-known and published, such as the one of Marie Bashkirtseff or that of Eugénie de Guérin. Lejeune wrote that Michelle Perrot, a pioneer of French women's history who in 1985 had already published Le journale intime de Caroline B., ${ }^{8}$ was the only colleague who believed in such an assumption, and showed interest in his work or, again in Lejeune's words, in his "voyage," offered as "un récit de voyage."9

What was revealed and expressed in this wonderful title Le Moi des Demoiselles suggested that young girls had their own selves, their own ways to search for and configure themselves-although this had been, as he finally examined on the basis of more than 100 unedited examples, much influenced by mothers or parents, educators, teachers ... But over time, young female diary-writers of the nineteenth and early twentieth centuries found modes of self-expression and individual adaption of the prescribed aims of diary-writing, described by Philippe Lejeune as a development of the "constitution and transgression" of a genre. We were delighted that he contributed a paper on this topic at a workshop that was held in Vienna in October 1994 with experts from several disciplines and autobiographical cultures reaching from Austria and Germany to Finland, Bulgaria and Turkey. ${ }^{10}$ Here, we discussed the tense relationship between the individuality and plurality of self-expression and normativity in various kinds of ego documents.

At the end of this workshop, it was decided to establish a transnational collaboration network in the field, which resulted-given that some of the attending scholars had already met at relevant conferences beforein the foundation of the working-group "EuroAutoText." This network was supposed to foster interdisciplinary research in Europe, by "focusing on the theoretical and methodological problems that arise from the textual dimensions of autobiographical writings and documents (autobiography, but also private diaries, correspondence, other personal documents, and oral history transcripts of life-stories"). ${ }^{11}$ Among the members of this group were Charlotte Heinritz from BIOS Institut für Geschichte und Biografie, Fernuniversität Hagen, Carolyn Steedman, University of Warwick-and Philippe Lejeune, who at that time had already founded the French Association pour l'autobiographie et le patrimoine/Association for Autobiography (A.P.A.) in Ambérieu-en-Bugey, France. 
But it seems that the times were not yet ripe for such a network. Perhaps one reason for this was the still existing prejudice which research on autobiographical texts of all forms, in particular against texts and collections of texts written by underprivileged people, had to encounter. This resulted in a lack of financial support furthered by the fact that national projects still needed much energy and time, the importance of international networking therefore coming only in second place. A further explanation lies in the rapid differentiation of the field and in the separate development of various strands of collecting and examining autobiographical texts in literary studies, ethnology, social history or "history from below", women's and gender history etc.

In Vienna, Edith Saurer had founded a collection of women's personal papers at the Department of History in 1990, where not only huge collections of private correspondence from the late $18^{\text {th }}$ to the $20^{\text {th }}$ century, but also-among other auto/biographical sources-thousands of (mostly female) diaries have been stored since then. At present, some 1230 volumes of diaries or, defined more openly, diary-like manuscripts are held here, which altogether also illustrate the hybridity of the genre. ${ }^{12}$ Scholarly publications based on this collection of diaries mostly written by women from the nineteenth century, and related lectures at the University of Vienna, usually refer to the work of Philippe Lejeune. His ground-breaking studies remain important and often-cited to the present day, together with the growing literature of feminist history/women's and gender history. ${ }^{13}$ Therefore we were glad that we could meet him again on the occasion of the foundation of EDAC-European Diary Archives and Collections in Amsterdam in June 2015, where he represented the French "Association pour l'autobiographie et le patrimoine/Association for Autobiography (A.P.A.)". Let us hope that this European network will survive and be successful in the future-which seems to be all the more important, as European togetherness, and expressions of common aims, interests and similarities have constantly to be renewed, what is also true for auto/biographical research and related activities. Philippe Lejeune has done a lot for this, and we cordially congratulate him on his $80^{\text {th }}$ birthday!

\section{ABOUT THE AUTHOR}

Christa Hämmerle is "Außerordentliche Universitätsprofessorin" of Modern History and Women's and Gender History at the Department of History of the University of Vienna, Austria, co-founder and -editor of L'Homme. Europäische Zeitschrift für Feministische Geschichtswissenschaft, and chair of the Sammlung Frauennachlässe (collection of women's personal papers). Among her fields of research 
are women or gender concepts/relations and war in the $19^{\text {th }}$ and $20^{\text {th }}$ century (especially the First World War, the Austro-Hungarian military from 1868 to 1914), the history of auto/biographical writings and the history of love. Her latest publications include: Heimat/Front. Geschlechtergeschichte/n des Ersten Weltkriegs in Österreich-Ungarn (Wien/Köln/Weimar: Böhlau 2014); with Ingrid Bauer (eds.), Liebe schreiben. Paarkorrespondenzen im Kontext des 19. und 20. Jahrhunderts (Göttingen: V \& R 2017); with Li Gerhalter (eds.), Krieg. Politik. Schreiben. Tagebücher von Frauen (1918 bis 1950) (Wien/Köln/Weimar: Böhlau 2015).

\section{NOTES}

1 Archives Autobiographiques. Publié sous la direction de Philippe Lejeune (= Cahiers de Sémiotique Textuelle 20, Université de Parix X 1991. This issue presented a range of European "Archives Autobiographiques" from different angles, including: Christa Hämmerle, Les archives "Récits de vie" à Vienna, pp. 103-113.

2 See for example Michael Mitterauer, "Ich in der Geschichte-Geschichte im Ich". Zur "Dokumentation lebensgeschichtlicher Aufzeichnungen" am Institut für Wirtschafts- und Sozialgeschichte der Universität Wien, in: Klaus Amann, Karl Wagner (eds.), Autobiographien in der österreichischen Literatur. Von Franz Grillparzer bis Thomas Bernhard, Innsbruck: Studienverlag 1998, pp. 241-269.

3 Dokumentation lebensgeschichtlicher Aufzeichnungen, see: https://wirtschaftsgeschichte.univie.ac.at/forschung/doku-lebensgeschichten/.

4 See for example: beiträge 7 zur feministischen theorie und praxis: Dokumentation der Tagung Weibliche Biographien in Bielefeld, München 1982; Carolyn Steedman, Landscape for a Good Woman. A Story of Two Lives, London: Virago Press 1986; Liz Stanley (ed.), Diaries of Hannah Cullwick, London: Virago Press 1984; idem, The auto/biographical I. The theory and practice of feminist auto/biography, Manchester/New York: Manchester University Press 1992 ( $1^{\text {st }}$ edition); Personal Narratives Group (ed.), Interpreting Women's Lives. Feminist Theory and Personal Narratives, Bloomington, Indianapolis: Indiana University Press 1989.

5 „Cher cahier ... “ Témoignages sur le journal personnel recueillis et présentés par Philippe Lejeune, Paris: Gallimard 1989.

6 Philippe Lejeune, "Cher Écran ..." Journal personnel, ordinateur, Internet, Paris: Éditions du Seuil 2000.

7 Full title: Philippe Lejeune, Le Moi des Demoiselles. Enquête sur le journal de jeune fille, Paris: Seuil 1993.

8 Le journal intime de Caroline B. Enquête de Michelle Perrot et Georges Ribeill, Paris: Éditions Montalba 1985.

9 Lejeune, Le Moi, p. 9.

10 Philippe Lejeune, French Girl's Diaries in the $19^{\text {th }}$ Century: Constitution and Transgression of a Genre, in: Plurality and Individuality. Autobiographical Cultures in Europe. Proceedings of an International Research Workshop at IFK Vienna, 21 $1^{\text {st }}-22^{\text {nd }}$ October 1994, edited by Christa Hämmerle, Vienna 1995.

11 EuroAutoText, Newsletter no. 1, February 1995, in: Hämmerle (ed.), Plurality and Individuality, 113-115, here 113.

12 See for example Christa Hämmerle, Diaries, in: Miriam Dobson and Benjamin Ziemann (eds.), Reading Primary Sources. The interpretation of texts from nineteenth- and twentieth-century history, London/New York: Routledge 2009, pp. 141-158. 
13 The "Sammlung Frauennachlässe" operates a regularly updated website with much detailed information on source material, MA and $\mathrm{PhD}$ theses written on their base, lectures, publications, media coverage, bibliographies on auto/biographical research etc.; see www. univie.ac.at/geschichte/sfn. See also, for example, Christa Hämmerle and Li Gerhalter, Tagebuch—Geschlecht—Genre im 19. und 20. Jahrhundert, in: ibid (eds.), Krieg. Politik. Schreiben. Tagebücher von Frauen (1918-1950), Wien/Köln/Weimar 2015, pp. 7-31; Li Gerhalter, Tagebücher als Quellen. Diaristische Aufzeichnungen als Forschungs- und Sammlungsgegenstände in den Sozialwissenschaften bis in die 1930er Jahre und in den Geschichtswissenschaften ab den 1980er Jahren, unpublished PhD thesis, University of Vienna 2017. 